\title{
Measuring Quality Determinants of Financial Statements
}

\author{
Widya Andelina ${ }^{1}$ \\ Aprih Santoso ${ }^{*}$ \\ ${ }^{1}$ Accounting Academy Effendi Harahap Semarang, Indonesia \\ ${ }^{2}$ Faculty of Economics at the Semarang University, Semarang, Indonesia
}

\begin{tabular}{ll}
\hline ARTICLE INFO & ABSTRACT \\
\hline ISSN: 2723-1097 & $\begin{array}{l}\text { The research aims to study the impact of the role of internal audit, the application } \\
\text { of regional accounting systems, and human resource competencies on the quality } \\
\text { of financial statements. A sample of } 141 \text { employees according to the purposive } \\
\text { sampling method and by distributing questionnaires. It turned out that the } \\
\text { Kuestionnaire returned was only from 138 employees. Data analyzed through } \\
\text { Keywords: }\end{array} \quad \begin{array}{l}\text { moderate regression analysis (MRA) from the SPSS program. The results of the } \\
\text { study stated that the role of internal audit has a negative impact on the quality of } \\
\text { financial statements, the application of regional accounting systems and human } \\
\text { resource competencies have a positive impact on the quality of financial } \\
\text { Competency, Quality of }\end{array}$ \\
Financial Statement
\end{tabular}

\section{Introduction}

Public accountability and transparency in managing public finances can be achieving by every state organization by providing reports on government responsibilities that are consistent with credible, relevant, comparable characteristics, and can be understood and governed by public accounting standards. The quality of a financial statement information is influencing by a reliable accounting system. Safrida, et.al. (2010), the quality of financial reports is poor because of the understanding of accounting with the preparation of financial statements and the subjective implementation of the regional accounting system, the role of internal audit and the ability of resources is weak.

Empirical studies have shown that many variables affect the quality of LKPD, including human resource competencies and the use of SAKD. The combination of these variables shows a vital role in producing high-quality financial statements. Human resources as technical implementors play an important role, starting from the process of preparing documents and ending with providing financial information to interested parties. SAKD is the use of information technology to speed up the accounting process. The Government (APIP) must able to make sure that all financial accounting and reporting processes are in accordance with the State Accounting Standards (SAP) for the preparation of financial statements.

Internal auditors of local governments are inspectors who will help local governments present high-quality and credible financial reports. Internal audit is a consultation, objective beliefs, and independent activities to add value and organizational performance (Safrida, et.al. 2010). The organization in realizing its aims is assisted by

Journal of Business and Management Review Vol. 2 No. 2021 Page 884-893

DOI: $10.47153 / j b m r 212.2082021$

${ }^{*}$ Corresponding Author

Email address: aprihsantoso@usm.ac.id 
internal auditing through systematic and disciplined methods to check and make the organization's effective oversight and management.

Events so far in connection with Demak's government financial reports are reports on the results of BPK's review with a fair opinion with an exception (WDP). BPK audit reports in the Demak governments are internal controls related to mismanagement of regional assets. Basic changes in accounting as a financial report preparation create new problems for local governments, ranging from accounting policies to technical analysis of transactions. The right approach to solve this problem is not possible for employees who lack an accounting knowledge (Indriasari \& Nahartyo, 2008). The preparation of quality financial reports requires competent human resources and adept at government accounting (Halim, $\underline{2015})$.

The combination of knowledge, skills, and abilities in a career that allows certain people to fulfill their task or function of excellence called competence (Boyatzis, 1982). In line with the preparation of accrual-based financial statements, it has become clear that this application requires supporting tools in the form of information technology systems. Information technology can accelerate the use of accrual-based financial statements (Macmillan, 2003). Therefore, the government issued Decree No. 56/2005, which requires local governments to use SAKD to regulate regional finances.

\section{Literature Review}

\section{Stewardship Theory}

Stewardship assumes that in financial reporting, governments that act as stewards have an obligation to present useful information for users of government financial information who act as principals in assessing accountability and making decisions both economic, social, and political decisions. In this case the government functions as a steward who is giving the authority to carry out certain obligations determined by the users of government financial information as principals, either directly or indirectly through their representatives. In agency relations, the government as an agent must carry out what is in the interests of users of government financial information as an agency relationship.

Donaldson (1898), motivated employees/managers to work in the company's need, and not for personal needs is Stewardship theory. Mardiasmo (2009) argues that in the context of public sector organizations, accountability is the responsibility of the authorities to mark the activities of people as trustees (principals) as experienced organizations that can successful and unsuccessful. Having reported financial reports, a government which is responsible for displaying information that is useful for users of government financial information act as the principal to assess responsibility and make economic, social and political decisions, in this case the government acts as a mandate given by the authorities to fulfill certainly obligations that have identified users of state financial information as actors, directly or indirectly through their representatives. financial information as an agency relationship.

\section{Decision-Usefulness Theory}

The financial reporting perspective that focuses on reporting information that is useful to investors are called a decision usefulness approach. In decision-usefulness theory, 
accounting information becomes a reference from the compilation of the Financial Accounting Standard Boards (FASB) conceptual framework, which is the Statement of Financial Accounting Concepts (SFAC) applicable in the United States (Kiswara, 2011). SFAC No.8 is intended to prove fundamental goals and concepts that will be the basis for the development of financial accounting and reporting guidelines so that the existing scope can meet the needs of the decision-makers who will use it.

The usefulness of information decision theory is very relevant because Government Accounting Standards in Indonesia adopt the qualitative characteristics of SFAC No. 2 its just that the Government Accounting Standards (SAP) contained in Law No. 71 of 2010 emphasizes four normative prerequisites: relevant, reliable, comparable and understandable.

\section{Quality of Financial Statements}

Halim (2015), says the results of business activities on information containing data on various elements of wealth structure and financial structure in the form of regional financial reports. The local government financial report consists of all the reports along with an explanation which states the report will approve from the financial report. Reporting financial statements of companies must consider the qualitative characteristics of the information displayed.

The qualitative characteristics of the information presented in the financial statements are important factors that must consider in presenting the company's financial statements. FASB in SFAC No. 2, qualitative characteristics are intending to be able to meet the basic provisions when using alternative methods of accounting and financial reporting and disclosure requirements.

\section{The Role of Internal Audit}

The Institute of Internal Auditors (1999) has redefined internal auditing, stating that internal auditing is an independent activity, objective beliefs and consultation designed to add value and improve organizational operations. Thus internal auditing helps the organization do its aims by applying a systematic and disciplined approach to evaluating and increasing the effectiveness of the process of managing the adequacy of organizational control and management. The scope and aims of the audit include reviewing the reliability of the reports presented, reviewing systems that have established to make sure compliance with policies, reviewing the ways in which companies protect the company's assets, assessing the colonization and efficiency of resource use, and reviewing various operations and programs pursued in achieving targets planned.

\section{Application of Regional Financial Accounting Systems}

Regional Financial Accounting System (SAKD) is a series of rules starting from the process of collecting data, recording, summarizing, up to financial reporting in the context of implementing the APBD that can do manually or using computer applications (Permendagri No. 59 of 2007). Azhar and Susanto (2001) states that: "Accounting information the system is an accounting data management system which is the coordination of humans, tools, and methods that interact harmoniously in a structured organization to produce financial accounting information and structured management accounting information as well. Dimensions of the Regional Financial Accounting System according 
to Nordiawan (2010), Bastian (2010), and Permendagri No. 13 of 2006 on the Guidelines for Regional Financial Management said that the regional financial accounting system includes (1) Recording. (2) Summary. (3) Reporting.

\section{Human Resource Competencies}

Decree of the Head of the State Civil Service Agency, No. 46A of 2003 determined that competence is the ability and characteristics possessed by a Civil Servant in the form of knowledge, skills, and attitudes (behavior) needed in the performance of his duties, so that the Civil Servant can carry out his duties professionally, effectively and efficiently. Baron \& Armstrong (2007), Competence is a behavioral dimension that is behind the competent performance. Often called behavioral competency because it is intended to explain how people behave when they carry out their roles properly. Hutapea and Thoha (2008), revealed that there are three main components of the formation of competencies, namely one's knowledge, abilities, and personal behavior.

\section{The Influence of the Role of Internal Audit on the Quality of Financial Statements}

Research on the Role of Internal Audit on the Quality of Financial Statements conducted by Safrida (2014) and Fikri (2015) found that the role of internal audit had a significant positive effect on the quality of financial statements. With the better process of supervision or review carried out by the role of the internal auditor (APIP) to government agencies will certainly improve the quality of information on LG financial statements. Financial statements that have the reliability of the value of information influenced by the inspector as an internal audit.

The review process of the financial statements determines whether the financial statements have been presented by applicable regulations. Input provided by the inspector in this review process will lead to the realization of financial statements that are in accordance with SAP, thereby improving the quality of the regional financial statements themselves. The existence of an internal auditor expected to give added value to the organization as an independent function, creating a professional attitude in each of its activities. Internal auditors are highly demanded their ability to give the best services and in accordance with what needed by an organization. Based on the description above, the research hypothesis is:

H1: The role of Internal Audit has a positive effect on the quality of financial statements.

\section{Effect of Application of Regional Financial Accounting Systems on the Quality of Financial Statements}

Along with the increasingly complex regional financial transactions and changes in accounting bases regulations, the government issued Government Regulation Number 56 of 2005 on Regional Financial Information Systems. The use of SAKD will greatly help speed up the processing of transaction data and the presentation of financial statements, so that the financial statements do not lose the value of information, namely timeliness (Haryanto, 2013). The Regional Financial Accounting System that implemented well, the better the Quality of Regional Financial Reports produced. Because basically the accounting system is a unit that if it is not implemented or there is one part of the system that is not implemented it is difficult to get the qualitative characteristics of Regional Financial Statements according to 
SAP which are relevant, reliable, understandable, and comparable. Andini and Yusrawati (2015) state that a well-implemented regional accounting system will produce good quality financial statements, based on the description above, the hypothesis of this research is :

H2: The application of the Regional Financial Accounting System has a positive effect on the quality of financial statements

\section{Effect of Competence of Human Resources on the Quality of Financial Statements}

HR competence is a characteristic of knowledge, ability, and behavior to do a job or do tasks and functions effectively. The more competent human resources are in making financial reports, the better the quality of the Regional Financial Reports produced. Employees who have high competence are very influential in the results of the preparation of financial statements, if these employees have high competence then the Quality of Regional Financial Statements will meet the qualitative characteristics. To add double-entry accrual accounting required by $\mathrm{HR}$ is a good understanding of accounting. Local government officials who deal with financial matters are not only enough to master the administration of the budget, but also must understand the characteristics of the transactions that occur and the effects on the accounts in the government's financial statements. The amount of local government financing against a non-accounting background is a major constraint now. Besides human factors, the inconsistency of the central government in issuing policies related to regional financial management is also a major cause of the slow development of regional finance. Andini and Yusrawati (2015), Hertati (2015) and Septarini (2016) stated that HR Competency influences the quality of regional financial reports. Based on the description above, the hypothesis of this study is:

H3: HR Competency has a positive effect on the Quality of Financial Statements.

\section{Method}

The population in this study was all SKPD in Demak Regency with a population of 47 SKPD, with a total of 410 employees. The sample taken in this study were employees in the financial sub-bag. The sampling technique in this study used a purposive sampling technique, which is a sampling technique based on certain criteria. The number of samples was 141 in this study.

Data analysis uses Moderated Regression Analysis (MRA). The results of the analysis are in the form of an instrument test, a classic assumption test, a model feasibility test, a hypothesis test, and regression analysis.

\section{Results And Discussion}

\section{Validity and Reliability Test}

The significance test is done by comparing the value of $r$ arithmetic with $r$ table for the degree of freedom $(\mathrm{df})=(\mathrm{N}-2=138-2=136, \mathrm{a}=0.05)$ which means the indicators indicate valid or valid to be examined. based on the results of calculations in the value of $r$-table $=0.140$. If $r$ count is greater and has a positive value compared to $r$ table, then 
each question is declared valid. The reliability test was carried out with the Cronbach Alpha statistical test. A constructor variable is said to be reliable if it gives a Cronbach Alpha value> 0.70 (Ghozali, 2011).

\section{Model Feasibility Test}

Table 1. Model Feasibility Test Results

\begin{tabular}{llrrr}
\hline & Model & Df & \multicolumn{1}{c}{ F } & Sig. \\
\hline 1 & Regression & 3 & 27.905 & $.000^{\mathrm{a}}$ \\
& Residual & 134 & & \\
Total & 137 & & \\
\hline
\end{tabular}

Based on the ANOVA test or the $\mathrm{F}$ test above, the calculated $\mathrm{F}$ value is $27.905>\mathrm{F}$ table 2.43. $(\mathrm{n}-\mathrm{k}-1=138-4-1=133, \mathrm{a}=0.05)$ with a probability of 0,000 . Because the probability value is smaller than 0.05 , the regression model can be used to predict the quality of financial statements.

Table 2. Determination Results Summary Model ${ }^{\mathrm{b}}$

\begin{tabular}{lrr}
\hline Model & $\begin{array}{c}\text { Adjusted R } \\
\text { Square }\end{array}$ & $\begin{array}{c}\text { Std. Error of the } \\
\text { Estimate }\end{array}$ \\
\hline 1 & .371 & 2.98960
\end{tabular}

Based on the results of the regression that has been done to produce an output model summary of adjusted $\mathrm{R}^{2}$ is 0.371 or $37.1 \%$, meaning that the dependent variable is influenced by the independent variable at $37.1 \%$. This is explained through calculations $(100 \%-37.1 \%=$ $62.9 \%)$, which means that $68 \%$ of the quality of regional financial reports is influenced by variables not examined.

Hypothesis Test (Statistics $\mathrm{t}$ )

\begin{tabular}{llrr}
\multicolumn{4}{c}{ Table 3. Test Results t } \\
\hline Model & $\begin{array}{c}\text { Standardized } \\
\text { Coefficients } \\
\text { Beta }\end{array}$ & T & Sig \\
& & & \\
\hline 1 (Constant) & -.152 & -2.148 & .034 \\
PIA & .470 & 6.396 & .000 \\
SAKD & .251 & 3.342 & .001 \\
SDM & & & \\
\hline
\end{tabular}

The effect of the independent variables on the dependent variable, for the value of $t$ table obtained from n-k-1 = 138-4-1 = 133 and the significance value of $5 \%$ amounted to 1,656 , the hypothesis concluded as follows:

1. The results of the Internal Audit Role variable on the Quality of Financial Statements show the $t$ value of -2.148 probability of $0.034<0.05$, it can be concluded that the 
hypothesis of the Internal Audit Role has a negative effect on the Quality of SKPD Financial Statements in Demak Regency, so the hypothesis first rejected.

2. The results of the study variable Implementation of Regional Financial Accounting Systems to the Quality of Financial Statements show the value of arithmetic of 6,396> $t$ table 1,656 with a significant probability of $0,000<0.05$, it can be concluded that the hypothesis of SAKD Application has a positive effect on the Quality of SKPD Financial Statements in Demak Regency, so that the hypothesis is second accepted.

3. The results of the HR Competency variable research on the Quality of Financial Statements show the $t$ value of 3,342> $t$ table 1,656 with a significant probability of $0.001<0.05$, it can be concluded that the HR Competency hypothesis has a positive effect on the Quality of SKPD Financial Statements in Demak Regency, so that the third the hypothesis is accepted.

\section{Discussion}

\section{Effect of Internal Audit's Role on the Quality of Financial Statements}

The results showed that the significance of the significance of the role of Internal Audit on the Quality of Financial Statements of 0.034 is below 0.05 or $0.034<0.05$ and the value of $t$ $=-2.148$ means that the Internal Audit Role has a significant negative effect on the Quality of Financial Statements. The results of this study are not in line with Safrida (2010) and Fikri (2015). Financial statements that have the reliability of the value of information is influenced by the inspector as an internal audit. The existence of an internal auditor expected to give added value to the organization as an independent function, creating a professional attitude in each of its activities. Internal auditors are highly demanded for their ability to give the best services and in accordance with what is needed by an organization. In this case the role of the district internal audit has not been able to be independent in the implementation of activities and reviews of financial statements, increasing competence and quality of the task implementation is inadequate so that in the supervision and review activities of local government agencies on the financial statements presented not produced a quality financial report quality.

\section{Effect of Application of Regional Financial Accounting Systems on the Quality of Financial Statements}

The results showed that the significance value of the application of the Regional Financial Accounting System to the Quality of Financial Statements of 0,000 was under 0.05 or $0,000<0.05$ and the value of $t=6.396$ means that the Application of the Regional Financial Accounting System had a significant positive effect on the Quality of Financial Statements. Based on the results of the study illustrates that respondents in Demak Regency SKPD have implemented a regional accounting system in preparing financial reports. The application of the accounting system was only implemented in 2015, this was done with the aim of facilitating it as well as effective and efficient in making financial reports. Frequency distribution for the variable implementation of the regional accounting system, where the average level of respondent achievement for the variable implementation of the regional accounting system is in a good category. With the implementation of this the regional financial accounting system, it can help the performance of Demak Regency employees in preparing financial reports, speeding up the transaction process and 
presenting financial reports, and obtaining BPK audits with WTP opinion. Utilization of SIKD will greatly help speed up the processing of transaction data and the presentation of financial statements, so that the financial statements do not lose the value of information, namely timeliness (

The results of this study support Andini and Yusrawati (2015) research which states that the Application of the Regional Financial Accounting System influences the Quality of Financial Statements. If the application of the regional financial the accounting system is applying in accordance with government accounting standards, the financial reports produced by each SKPD Demak Regency are of good quality.

\section{Effect of Competence of Human Resources on the Quality of Financial Statements}

The results showed that the significance value of the significance of Human Resources Competence on the Quality of Financial Statements of 0.001 was below 0.05 or $0.001<0.05$ and $\mathrm{t}$ value $=3.342$ means that Human Resources Competence had a significant positive effect on the Quality of Financial Statements. To do the effectiveness of financial management, the government must have competent human resources. The more competent the HR of the Financial Statement makers, the better the Quality of the Financial Statements produced so that they meet the qualitative characteristics of the financial statements. The results of this study support the research conducted by Andini and Yusrawati (2015) which states that HR competence has a significant positive effect on the quality of financial statements. If employees have competencies that are proper to their field of work, the resulting financial statements are of high quality.

\section{Conclusion}

The conclusion that can be taken in this research are: (1) The application of PIA has a negative effect on the Quality of SKPD Financial Statements in Demak Regency. (2) The application of SAKD has a positive effect on the quality of the Demak Regency SKPD Financial Statements. (3) HR competency has a positive effect on the quality of SKPD Demak Regency's Financial Statements.

The suggestions that can give are: (1) The Demak Regency Government expected to continue to give direction related to the application of SAKD to every employee in the SKPD with the aim of implementing the regional accounting the system in accordance with applicable government standards by conducting training, socialization related to the system used. (2) Demak Regency Government is expected to always improve the competency of human resources on a regular basis by conducting educational, training and training activities related to the preparation of financial reports to improve the quality of financial reports.

\section{References}

Andini, D., Yusrawati. (2015). Pengaruh Kompetensi Sumber Daya Manusia dan Penerapan Sistem Akuntansi Keuangan Daerah Terhadap Kualitas Laporan Keuangan Daerah Pada Satuan Kerja Perangkat Daerah (SKPD) Kabupaten Empat Lawang Sumatera Selatan. Jurnal Ekonomi KIAT, 24(1), 65-82.

Azhar, La Midjan dan Susanto, (2001), Sistem Informasi Akuntansi I dan II, Edisi Ke Sebelas, Lembaga Informasi, Bandung 
Baron, Anggela \& Amstrong, Michael. (2007). Human Capital Management: Achieving Added Value Through People. London: Kogan Page Publishers

Bastian, I. (2010). Akuntansi sektor publik. Jakarta: Erlangga

Botutihe, T. H., Noholo, S., \& L.A ODE, R.A.S.U.L.I. (2013). Pengaruh Penerapan Sistem Akuntansi Keuangan Daerah Terhadap Kualitas Laporan Keuangan Pemerintah Kota Gorontalo. KIM Fakultas Ekonomi \& Bisnis, 1(1) : 81-92

Boyatzis, R.E. (1982). The competent manager: a model for effective performance. New York: John Wiley and Sons.

Diani, D. I. (2014). Pengaruh Pemahaman Akuntansi, Pemanfaatan Sistem Informasi Akuntansi Keuangan Daerah Dan Peran Internal Audit Terhadap Kualitas Laporan Keuangan Pemerintah Daerah (Studi Empiris pada Satuan Kerja Perangkat Daerah di Kota Pariaman). Jurnal Akuntansi, 2(1) : 29-38

Donaldson, L., Davis, J.H. (1989). “Stewardship Theory or Agency Theory: CEO Governance and Shareholder Returns".Australian Journal of Management, 16: 49-64.

Fikri, M., Rejeki, S., \& Widowati, L. L. (2015). PRODUKSI DAN KUALITAS RUMPUT LAUT (Eucheuma cottonii) DENGAN KEDALAMAN BERBEDA DI PERAIRAN BULU KABUPATEN JEPARA. Journal of Aquaculture Management and Technology, 4(2), 67-74. Retrieved from https:/ / ejournal3.undip.ac.id/index.php/jamt/article/view/854.

Ghozali, I. (2011). Aplikasi Analisis Multivariate dengan Program IBM SPSS 21 Upadate PLS Regresi. Semarang: Badan Penerbit Universitas Diponegoro.

Halim. A., (2015). Auditing (Dasar-dasar Audit Laporan Keuangan). Jilid 1. Edisi Kelima. Yogyakarta : UPP STIM YKPN

Haryanto. (2013). Pengelolaan dan Akuntansi Keuangan Daerah. Edisi Pertama. Semarang:. Undip Press.

Hertati, L. (2015). Competence of Human Resources, The Benefit of Information Technology on Value of Financial Reporting in Indonesia. Research Journal of Finance and Accounting. 6 (8) : 63-79

Hutapea, Parulian dan N. Thoha. (2008). Kompetensi Plus. Jakarta : PT. Gramedia Pustaka Utama.

Ihsanti, E. (2014). Pengaruh Kompetensi Sumber Daya Manusia Dan Penerapan Sistem Akuntansi Keuangan Daerah Terhadap Kualitas Laporan Keuangan Daerah (Studi Empiris pada SKPD Kab. Lima Puluh Kota). Jurnal Akuntansi, 2(3) : 41-54.

Indriasari, D. \& Nahartyo, E. (2008). Pengaruh Kapasitas Sumber Daya Manusia, Pemanfaatan Teknologi Informasi dan Pengendalian Intern Akuntansi Terhadap Nilai Informasi Pelaporan Keuangan Pemerintah Daerah (Studi pada Pemerintah Kota Palembang dan Kabupaten Ogan Illir). Kumpulan Simposium Nasional Akuntansi XI di Pontianak, 23-24 Juli

Indriasih, D. (2014). The Effect of Government Apparatus Competence and the Effectiveness of Government Internal Control Toward the Quality of Financial Reporting in Local Goverment. Research Journal of Finance and Accounting, 5 (20): 38-47.

Kalumata, M. C., Ilat, V., \& Warongan, J. D. (2016). Pemgaruh Kompetensi Sumber Daya Manusia, Teknologi Informasi, Reviuw Laporan Keuangan dan Sistem Pengendalian Internal Terhadap Kualitas Laporan Keuangan Pada Pemerintah Provinsi Sulawesi Utara. Accountability, 5(2) : 79-92

Kiswara, E. (2011). Nilai Relevan Dan Reliabilitas Kegunaan-Keputusan Informasi Akuntansi Menurut Sfac No. 2 Dalam Penyajian Laporan Keuangan Dengan Metode-Metode Pembebanan Pajak Penghasilan Berbeda (Doctoral dissertation, Universitas Diponegoro). 
Macmillan, G. (2003). Improving Government Financial Reporting: The Window to Good Governance. The Governance Brief. [cited 2015 Sep. 18]. Available from,URL:http://www.adb.org/sites/default/files/publication/28640/governance brief09.pdf.

Mardiasmo. 2009. Perpajakan, edisi revisi tahun 2009.Yogyakarta: Andi.

Martoyo, S (2002). Manajemen Sumber Daya Manusia, Yogyakarta: Badan Penerbit Universitas Gajah Mada

Mensah, B.K.A (2013). Adoption of International Financial Reporting Standards (IFRS) in Ghana and the Quality of Financial Statement Disclosures. International Journal of Accounting and Financial Reporting, 3 (2): 269-286

Nadir, R., \& Hasyim, H (2017). Pengaruh Pemanfaatan Teknologi Informasi, Kompetensi Sumber Daya Manusia, Terhadap Kualitas Laporan Keuangan Pemerintah Daerah Dengan Variabel Intervening Standar Akuntansi Pemerintahan Berbasis Akrual (Studi Empiris Di Pemda Kabupaten Barru). AKUNTABEL, 14 (1), 57-68.

Nordiawan, Deddi. (2010) Akuntansi Sektor Publik, Jakarta : Salemba Empat

Safrida, Y., Nadirsyah dan U. Bakar (2010). Pengaruh Pemahaman Akuntansi, Pemanfaatan Sistem Informasi Akuntansi Keuangan Daerah dan Peran Internal Audit Terhadap Kualitas Laporan Keuangan Pemerintah Daerah (Studi pada Pemerintah Kota Banda Aceh). Jurnal Telaah \& Riset Akuntansi. 3 (2) : 206-220.

Schick, A .G., Gordon, L. A., and Haka, S (1990). Information Overload: A Temporal Approach. Accounting, Organizations and Society, 15 (3): 199-220.

Septarini, D. F., \& Papilaya, F. (2016). Interaksi Komitmen Organisasi terhadap Faktor Faktor yang mempengaruhi Kualitas Laporan Keuangan Pemerintah Daerah. Jurnal Ilmu Ekonomi \& Sosial, 7(2), 100-116.

Sugijanto. (2002). Peranan Sistem Akuntansi Pemerintah Pusat Dalam Meningkatkan Akuntabilitas Keuangan dan Implikasi Undang-Undang Nomor 22/25 Tahun 1999". Lintasan Ekonomi, 19 (1): 50-66.

Sugiyono. (2008). Metode Penilitian Bisnis. Alfabeta: Bandung.

Suryanto. S,O. (2015). Analysis The Use Of International Financial Reporting Standards (IFRS) In PT. Telekomunikasi Indonesia, Tbk. European Journal of ccounting Auditing and Finance Research, 3 (3): 86 - 98.

Zeyn, E. (2011). Pengaruh Good Governance dan Standar Akuntansi Pemerintahan Terhadap Akuntabilitas Keuangan dengan Komitmen Organisasi Sebagai Pemoderasi. Jurnal Reviu Akuntansi dan Keuangan. 1(1) : 21-37 